\title{
TEKNIK DOKUMENTASI DAN PELAPORAN DALAM TATARAN \\ KLINIK
}

\section{Queen Agave (Queenasiregar@gmail.com)}

\section{Latar Belakang}

Dalam dunia kesehatan informasi kesehatan dan teknologi kesehatan sudah tidak asing lagi dan dijadikan sebagai sarana penunjang dalam penerapannya.Era globalisasi dan informasi telah dijadikan penunjang di segala sektor dalam Negara kita. Salah satunya dalam dunia kesehatan, era globalisasi dan informasi seakan telah membuat standar baru yang harus dipenuhi oleh seluruh pemain di sektor ini.Hal tersebut telah membuat dunia keperawatan di Indonesia membuat dunia keperawatan di Indonesia menjadi menjadi tertantang untuk mengembangkan kualitas pelayanan keperawatan yang berbasis teknologi informasi. Namun tentunya tidak luput dari hambatan-hambatan yang dihadapi oleh keperawatan di Indonesia, diantaranya adalah keterbatasan SDM yang menguasai bidang keperawatan dan teknologi informasi, masih minimnya infrastruktur untuk menerapkan system informasi di dunia pelayanan, dan masih rendahnya minat para perawat di bidang teknologi informasi kesehatan. Kualitas atau mutu pelayanan keperawatan di rumah sakit bergantung kepada kecepatan, kemudahan, dan ketepatan dalam melakukan tindakan keperawatan yang berarti dalam melakukan tindakan keperawatan yang berarti juga pelayanan uga pelayanan keperawatan. Pelayanan yang bersifat medis khususnya di pelayanan keperawatan mengalami perkembangan teknologi informasi yang sangat membantu dalam proses keperawatan dimulai dari pemasukan data secara digital ke dalam komputer.

Tenaga keperawatan merupakan ujung tombak dalam pelayanan kesehatan, karena memiliki proporsi yang paling besar dan melakukan asuhan secara komperhensif kepada pasien selama 24 jam, karenanya seorang perawat harus dapat memberikan pelayanan kesehatan yang berkualitas sesuai dengan standar asuhan keperawatan, mulai dari pengkajian sampai dengan evaluasi. 


\section{Metode}

Metode ini menggunakan metode kualitatif analisis berlandaskan teori dari buku, jurnal, e-book ataupun sumber informasi lainnya yang memuat informasi dengan pembahasan peran perawat dalam mencegah terjadinya hazard di rumah sakit. Dengan metode ini

\section{Hasil}

Dokumentasi adalah catatan yang dapat dibuktikan atau dapat menjadi bukti secara hukum. ( Tung Palan ). Dokumentasi yaitu setiap penglihatan / bukti fisik dapat berupa tulisan, foto, video klip, kaset dan lain-lain, yang telah dilakukan dan dpat dikumpulkan / dipakai kembali ( thyredot ) atau semua data. Otentik yang dapat dibuktikan secara hukum dan dapat dipertanggung jawabkan sesuai dengan aturan dan dapat digunakan untuk melindungi klien ( Informed Concent ). Dokumentasi keperawatan adalah metode sistematis untuk mengidenfikasi masih klien, merencanakan, menimplementasi strategi pemecahan masalah mengevaluasi efektifitas dari tindakan keperawatan yang telah diberikan. ( Kozier dan ERB ) Dokumentasi adalah suatu dokumen yang berisi data lengkap, nyata, dan tercatat bukan hanya tentang tingkat kesakitan pasien tetapi juga jenis dan kualitas pelayanan kesehatan yang informasi pembahasan mengenai dokumentasi keperawatan dapat memahami dan mempelajari bagaimana teknik dokumentasi dan pelaporan dalam tataran klinik.

diberikan. ( Fisbach, 1991 ). Dokumentasi keperawatan adalah suatu catatan yang memuat seluruh informasi yang dibutuhkan untuk menentukan diagnosis keperawatan, menyusun rencana keperawatan, melaksanakan dan mengevaluasi tindakan keperawatan yang disusun secara sistematis, valid, dan dapat dipertanggungjawabkan. (Zaidin Ali, 1998 ). Dari beberapa definisi di atas, dapat disimpulkan bahwa pondokumentasian adalah sebagai berikut :

1. Informasi mencakup aspek biologis, psikologis, social, dan spiritual, yang terjadi pada setiap tahap proses keperawatan yang dicatat secara menyeluruh.

2. Informasi yang diperoleh menjadi dasar bagi penegakan diagnosis keperawatan, pembuatan rencana keperawatan, implementasi, dan evaluasi asuhan keperawatan dan menjadi umpan balik selanjutnya. 


\section{Pembahasan}

1. Informatika Keperawatan

Perawat merupakan salah satu tenaga kesehatan yang memegang peranan penting dalam mencapai tujuan pembangunan kesehatan, dimana pelayanan keperawatan menurut Gillies (1996), sangat menentukan kualitas pelayanan kesehatan di rumah sakit secara keseluruhan, hal ini terkait erat dengan tugas perawat yang selama 24 jam melayani klien dan jumlah perawat yang mendominasi tenaga kesehatan di rumah sakit yaitu sekitar $40-60 \%$ ( Swanburg, 2000). Keperawatan melingkupi pelayanan secara otonom dan kolaboratif bagi individu dari segala usia, keluarga, kelompok, dan komunitas, sakit ataupun sehat dalam segala latar, yang mencakup promosi kesehatan, pencegahan penyakit, dan perawatan orang sakit, cacat, atau akan meninggal. Perawat merupakan salah satu tenaga kesehatan yang memegang peranan penting dalam mencapai tujuan pembangunan kesehatan, dimana pelayanan keperawatan menurut Gillies (1996), sangat menentukan kualitas pelayanan kesehatan di rumah sakit secara keseluruhan, hal ini terkait erat dengan tugas perawat yang selama 24 jam melayani klien dan jumlah perawat yang mendominasi tenaga kesehatan di rumah sakit yaitu sekitar $40-60 \%$ ( Swanburg, 2000). Keperawatan melingkupi pelayanan secara otonom dan kolaboratif bagi individu dari segala usia, keluarga, kelompok, dan komunitas, sakit ataupun sehat dalam segala latar, yang mencakup promosi kesehatan, pencegahan penyakit, dan perawatan orang sakit, cacat, atau akan meninggal.

Informatika keperawatan adalah penggunaan teknologi informasi sehubungan dengan tiap fungsi yang ada dalam bidang keperawatan dan dilakukan oleh perawat dalam pelaksanaan tugas mereka. Hal ini mencakup perawatan klien, administrasi, pendidikan,dan penelitian (Hannah, 1985). Informatika keperawatan adalah kombinasi ilmu komputer, ilmu informasi, dan ilmu keperawatan yang dirancang untuk membantu manajemen dan pemrosesan data, informasi, dan pengetahuan keperawatan untuk menunjang praktek keperawatan dan penyampaian layanan keperawatan (Graves \& Corcoran, 1989). Menurut Goossen (1996) Informatika 
keperawatan: adalah upaya ilmiah multidisiplin untuk analisis, formalisasi, dan pemodelan cara perawat mengumpulkan dan mengelola data, memproses data menjadi informasi dan pengetahuan, membuat keputusan berbasis pengetahuan dan inferensi bagi perawatan klien, serta menggunakan pengetahuan empirik dan berdasarkan pengalaman ini untuk memperluas wawasan dan meningkatkan kualitas praktek profesional mereka (Goossen, 1996).

Sistem informasi keperawatan merupakan kombinasi dari ilmu komputer, informasi dan keperawatan yang disusun untuk mempermudah manajemen, proses pengambilan keputusan, dan pelaksanaan asuhan keperawatan. Salah satu penggunaan sistem informasi keperawatan di kembangkan pada tahun 1960-1970 -an adalah dengan pendokumentasian keperawatan terkomputerisasi. Pendokumentasian terkomputerisasi memfasilitasi pembakuan klasifikasi asuhan keperawatan sehingga menghilangkan ambiguitas dalam pendokumentasian keperawatan. Sedangkan menurut ANA (Vestal, Khaterine, 1995) sistem informasi keperawatan berkaitan dengan legalitas untuk memperoleh dan menggunakan data, informasi dan pengetahuan tentang standar dokumentasi, komunikasi, mendukung proses pengambilan keputusan, mengembangkan dan mendesiminasikan pengetahuan baru, meningkatkan kualitas, efektifitas dan efisiensi asuhan keperawaratan dan memberdayakan pasien untuk memilih asuhan kesehatan yang diiinginkan. Kehandalan suatu sistem informasi pada suatu organisasi terletak pada keterkaitan antar komponen yang ada sehingga dapat dihasilkan dan dialirkan menjadi suatu informasi yang berguna, akurat, terpercaya, detail, cepat, relevan untuk suatu organisasi.

\section{Fungsi Sistem Informasi} Keperawatan

Konseptual model dalam sistem informasi keperawatan berdasarkan 4 fungsi utama dalam praktik keperawatan klinik dan administratif:

a. Proses perawatan pasien

Proses perawatan pasien adalah apa yang telah dilakukan oleh perawat kepada pasien yaitu: 
pengkajian, diagnosa

keperawatan, jadwal

perawatan dan pengobatan,

catatan keperawatan, pola

makan, prospektif, beban

kerja, administrasi pasien.

b. Proses managemen bangsal

Aktivitas yang berhubungan dengan fungsi bangsal untuk secara efektif menggunakan menggunakan sumber dalam merencanakan objek secara spesifik. Mentransformasikan informasi pada manajemen yang berorientasi informasi dalam pengambilan keputusan: jaminan kualitas, sudut pandang aktivitas di bangsal keperawatan, jadwal dinas karyawan, manajemen perseorangan, perencanaan keperawatan, manajemen inventarisasi dan penyediaan sarana dan prasarana, manajemen finansial, kontroling terhadap infeksi.

c. Proses komunikasi

Seluruh

aktivitas

dikonsentrasikan pada komunikasi pada pasien dan subjek lain yang memiliki hubungan dengan subjek pengobatan, perjanjian dan penjadwalan, review data, transformasi data, dan segala bentuk pesan.

d. Proses Pendidikan dan Penelitian Pendokumentasian fungsi dan prosedural.

3. Keuntungan Menggunakan Sistem Informasi Keperawatan

a. Penghematan biaya dari penggunaan kertas untuk pencatatan

b. Penghematan ruangan karena tidak dibutuhkan tempat yang besar dalam penyimpanan arsip.

c. Penyimpanan data pasien menjadi lebih lama.

d. Membantu dalam mencari informasi yang cepat sehingga dapat membantu pengambilan keputusan secara cepat

Sedangkan menurut Holmes (2003, dalam Sitorus 2006), terdapat keuntungan utama dari dokumentasi berbasis 
komputer yaitu:

a. Standarisisasi:

terdapat

pelaporan data

klinik yang

standar, mudah

dan cepat

diketahui.

b. Kualitas:

meningkatkan

kualitas

informasi klinik

dan sekaligus

meningkatkan

waktu perawat

dalam

memberikan

asuhan

keperawatan.

c. Accessebility, legibility:

mudah

membaca dan

mendapat

informasi klinik

dari pasien

dalam satu

lokasi.
4. Aplikasi Sistem Informasi Dalam Dokumentasi

Asuhan

Keperawatan

Dokumentasi perawatan merupakan bagian penting dari dokumentasi klinis. Namun, dokumentasi proses keperawatan sering kurang berkualitas. Untuk meningkatkan dokumentasi asuhan keperawatan yang dilakukan oleh perawat maka perlu diterapkan sistem infomasi keperawatan

dalam pendokumentasian asuhan keperawatan. Ada harapan tinggi bahwa komputer dapat mendukung dalam dokumentasi keperawatan akan membantu meningkatkan kualitas dokumentasi. Namun dengan diterapkannya komputerisasi di rumah sakit juga perlu diimbangi oleh kemampuan perawat dalam mengoperasionalkan komputer. Untuk meningkatkan kemampuan perawat dalam penggunaan komputer maka perawat telah menyoroti kebutuhan untuk pelatihan dalam penggunaan teknologi informasi, dan penilaian kritis penting untuk 
profesional perawat. (Docker, et all.,2003)

Program yang dikembangkan dalam penyusunan system dokumentasi keperawatan berbasis computer adalah sebagai berikut :

a. Standar Asuhan Keperawatan

Standar Asuhan Keperawatan menggunakan standar Internasional dengan mengacu pada Diagnosa Keperawatan yang dikeluarkan oleh North American Nursing Diagnosis Association, standar outcome keperawatan mengacu pada Nursing Outcome Clasification dan standar intervensi keperawatan mengacu pada Nursing Intervention Clasification (NIC) yang dikeluarkan oleh Iowa Outcomes Project.

b. Daftar NIC terbanyak

Daftar NIC terbanyak adalah rekapan tindakan keperawatan terbanyak berdasarkan pada masing-masing diagnosa keperawatan yang ada di masiangmasing unit ataupun tingkat RS.

c. Daftar Standar Asuhan Keperawatan

Standar Asuhan Keperawatan (SAK) yang ideal adalah berdasarkan evidence based nursing, yang merupakan hasil penelitian dari penerapan standar asuhan keperawatan yang ada. Namun karena dokumen yang tidak lengkap, SAK banyak diadopsi hanya dari omputere yang tersedia. Dengan terdapatnya data ini nantinya evidence base nursing dapat ditampilkan sehingga Standart Asuhan Keperawatan akan direvisi lagi sesuai dengan hasil kajian dan kenyataan yang ada di pelayanan keperaaatan berdasarkan pada rekapitulasi SAK berdasarkan rekapan dari sistem yang telah dibuat.

\section{d. Standart Operating Procedure (SOP)}

Standart Operating Procedure (SOP) adalah uraian standar tindakan perawatan yang terdapat 
dalam standar asuhan keperawatan. SOP merupakan aktifitas detail dari NIC. SOP tindakan keperawatan yang baru direvisi berjumlah 110 jenis SOP yang terbagi dalam 11 kategori, dimana ketika tindakan ini dilakukan akan link dengan pemakaian bahan dan alat kesehatan yang ada sehingga floor stok barang / alat medis dan keperawatan akan berkurang secara otomatis.

e. Jadwal Dinas Perawat Jadwal dinas perawat dibuat secara otomatis oleh program omputer, dengan memperhatikan pembagian SDM keperawatan dari jenjang klinik keperawatan / Perawat Klinik 1,2,3 serta perencanaan cuti yang telah disusun sebelumnya, sehingga penanggung jawab ruang tinggal melakukan print.

f. Perhitungan angka kredit perawat

Penghitungan angka kredit sebagai dasar kenaikan golongan yang selama ini dikerjakan oleh tenaga keperawatan akan lebih mudah difasilitisi dengan SIM keperawatan ini, dimana tinggal melihat rekap kegiatan yang telah dilakukan selama ini di ruang perawatan. Rekapan kegiatan aktifitas

perawat sehari-hari yang merupakan dasar penghitungan kredit point ini secara otomatis akan dapat diakses secara harian, mingguan atau bulanan.

g. Daftar diagnosa keperawatan terbanyak.

Rekapitulasi daftar diagnose terbanyak ini dapat diakses berdasarkan masingmasing ruangan, dan juga dapat diakses dari seuruh ruangan. Hal Ini dapat dilakukan ketika daftar diagnose yang telah dilakukan dimasing- masing ruangan. 


\section{Penutup}

Kesimpulan

Teknologi dalam kesehatan

mempunyai peran yang

sangat penting,terutama dalam

memberikan kualitas atau mutu

pelayanan kesehatan di Rumah

Sakit.Seiring dengan

perkembangan teknologi dan

informasi seakan telah membuat

standar baru yang harus di

penuhi.Hal tersebut membuat

keperawatan di Indonesia menjadi

tertantang untuk terus mengembangkan kualitas

pelayanan keperawatan yang

berbasis teknologi informasi.

Saran

Pemerintah atau lembaga kesehatan hendaknya segera meningkatkan standar dan mutu sistem kesehtan di Indonesia, terutama yang berhubungan dengan teknologi karena bila di bandingkan dengan negara lain ini masih sangat tertinggal.Untuk membenahi hal tersebut maka harus di butuhkan solusi cerdas. 


\section{Daftar Pustaka}

1. AGUSTINUS, A. (2015). HUBUNGAN MOTIVASI PERAWAT DENGAN KELENGKAPAN DOKUMENTASI ASUHAN KEPERAWATAN DI RUANG RAWAT INAP ELISABETH RUMAH SAKIT PANTI RAPIH YOGYAKARTA MARET 2015 (Doctoral dissertation, STIKES Bethesda Yakkum Yogyakarta).

2. CLARA, N. (2016). FAKTOR-FAKTOR YANG BERHUBUNGAN DENGAN KUALITAS DOKUMENTASI ASUHAN KEPERAWATAN DI RUANG RAWAT INAP RUMAH SAKIT ISLAM IBNU SINA PADANG TAHUN 2016 (Doctoral dissertation, Universitas Andalas).

3. KURNIAWAN, D. (2019). ANALISA PENERAPAN BUKU SAKU DALAM MENINGKATAN MUTU PELAYANAN DAN DOKUMENTASI KEPERAWATAN DI BALAI KESEHATAN PARU MASYARAKAT PURWOKERTO (Doctoral dissertation, UNIVERSITAS MUHAMMADIYAH PURWOKERTO).

4. MARZA, R. (2014). DOKUMENTASI ASUHAN KEPERAWATAN PADA PELAKSANAAN RANGE OF MOTION PASIEN STROKE DI RUANG RAWAT INAP SARAF BLUD RUMAH SAKIT UMUM DR. ZAINOEL ABIDINRN BANDA ACEH TAHUN 2013. ETD Unsyiah.

5. Nuryani, N., \& Susanti, D. D. (2014). Hubungan Pengetahuan Perawat dengan Kelengkapan Dokumentasi Asuhan Keperawatan di RSUD dr. Soekardjo Kota Tasikmalaya. Jurnal Manajemen Informasi Kesehatan Indonesia (JMIKI), 2(2).

6. Pakudek, K. H., Robot, F., \& Hamel, R. (2014). Hubungan motivasi perawat dengan pelaksanaan dokumentasi asuhan keperawatan di instalasi rawat inap C RSUP Prof. Dr. RD Kandou Manado. Jurnal Keperawatan, 2(2).

7. PRASTANTI, D. W. (2012). Hubungan Kelengkapan Dokumentasi Keperawatan Dengan Mutu Pelayanan Keperawatan Di Ruang Melati RSUD Prof. Margono Soekarjo Purwokerto (Doctoral dissertation, UNIVERSITAS MUHAMMADIYAH PURWOKERTO).

8. Puspitasari, S. (2013). FAKTOR-FAKTOR DALAM PELAKSANAAN DOKUMENTASI KEPERAWATAN DI RSUD MAJALAYA.

9. Simamora, R. H., Purba, J. M., Bukit, E. K., \& Nurbaiti, N. (2019). Penguatan Peran Perawat Dalam Pelaksanaan Asuhan Keperawatan Melalui Pelatihan Layanan Prima. JPPM (Jurnal Pengabdian Dan Pemberdayaan Masyarakat), 3(1), 25-31.

10. Simamora, R. (2009). Dokumentasi Proses Keperawatan.

11. Syahida, A., \& Rahayu, D. (2019). Faktor Yang Berhubungan dengan Kepatuhan Perawat dalam Pelaksanaan Dokumentasi Asuhan Keperawatan di Ruang Rawat Inap Mata Uroe BLUD RSUD Langsa. Jurnal EDUKES (Jurnal Penelitian Edukasi Kesehatan), 50-59.

12. Yanti, R. I., \& Warsito, B. E. (2013). Hubungan karakteristik perawat, motivasi, dan supervisi dengan kualitas dokumentasi proses asuhan keperawatan. Jurnal Manajemen Keperawatan, 1(2). 
